\title{
Diaspora, ojczyzny i pamięć w życiu ukraińskich migrantów z Polski w Kanadzie
}

\section{Abstract \\ Diaspora, Homelands and Memory in Lives of Ukrainian Migrants from Poland in Canada}

The basis for this article is ethnographic field research carried out in Canada in 2014-2016 among Ukrainians who emigrated from Poland in 1980s and met vibrant Ukrainian diaspora built by earlier generations of Ukrainian migrants. The author analyses the encounter of official, diasporic discourses of the Ukrainian past with the local history of Ukrainians from Poland, especially displacement of 1947, spaces of self-presentation, role and significance of images of Poland and Ukraine in their lives, their involvement in wider Ukrainian context in Canada, contacts with the local Polish diaspora, problems with explicit identity assignment and a specific group distinctiveness that is a challenge for the essentialistically understood diaspora. In return, she proposes to consider the part of the Ukrainian diaspora as a transnational imaginary community (the concept of M. Sökefeld), and to follow the attitudes, practices and ideas of both the diaspora and the native country.

Keywords: diaspora, memory, Ukrainians from Poland, Canada.

\section{Uwagi wstępne}

W opracowaniach podejmujących wątek wyjazdów z Polski do Kanady i USA w latach 80. emigrantów określa się jako Polaków. Tymczasem wśród nich było wiele osób ukraińskiego pochodzenia - obywateli Polski, potomków wysiedlonych w ramach akcji „Wisła” z ukraińskich bądź mieszanych wsi w Polsce Wschodniej 
i Południowo-Wschodniej. Organizacja Zakerzonie z Toronto, zrzeszająca wychodźców z Polski z lat 80., ocenia, że w samym Toronto mogło to być od 5 do 10 tysięcy osób. Jest to zatem klasyczny błąd nacjonalizmu metodologicznego (Wimmer, Glick Schiller 2002), polegający na utożsamieniu emigrantów z państwem narodowym, $\mathrm{z}$ którego emigrują.

W latach 2014-2016 prowadziłam w Kanadzie w tym środowisku etnograficzne badania terenowe ${ }^{1}$. Łącznie spędziłam w terenie 12 miesięcy, w trakcie których prowadziłam obserwacje, wywiady i nieformalne rozmowy, spędzałam czas z moimi rozmówcami, śledziłam ich aktywność na Facebooku i w ukraińskich organizacjach. Materiału dostarczyły mi także obserwacje imprez kulturalnych i festiwali ukraińskich, wizyty w ukraińskich instytucjach kulturalnych, społecznych i naukowych, analiza prasy ukraińskiej i polskiej ukazującej się w Toronto, statutów ukraińskich organizacji, a przede wszystkim zamieszkiwanie z ukraińską rodziną z Polski i spędzanie czasu z wieloma osobami z tej grupy (imprezy rodzinne i towarzyskie, wyjazdy za miasto, wspólne gotowanie, posiłki, zakupy, oglądanie kanadyjskiego programu informacyjnego etc.).

Osoby ukraińskiego pochodzenia, które w latach 80 . zdecydowały się na emigrację do Kanady, od dziecka funkcjonowały w warunkach rozproszenia, presji asymilacyjnej, konieczności ukrywania własnej tożsamości etnicznej i wielokrotnie zmagały się z doświadczeniami dyskryminacji, opartej na negatywnym stereotypie etnicznym. Głęboka deprywacja obywatelska i ekonomiczna tego czasu (Mazurek 2010) okazała się ostatecznie czynnikiem, który ułatwił im i przyspieszył decyzję o wyjeździe z kraju w poszukiwaniu lepszych szans dla siebie i swoich dzieci. Zdecydowana większość trafiła do Kanady przypadkowo, na skutek decyzji urzędnika w obozie przejściowym dla uchodźców z krajów socjalistycznych w austriackim Traiskirchen. Już na miejscu czekała jednak na nich pomoc organizacyjna i finansowa środowisk ukraińskich, które zapewniły młodym uciekinierom z Polski start w Kanadzie i złagodziły szok emigracji. Kontakt z miejscowymi Ukraińcami (głównie z pokoleniem ich rodziców) i instytucjami diaspory w wie-

1 W 2014 r. przebywałam na półrocznym stażu naukowym w Canadian Institute of Ukrainian Studies w Univeristy of Alberta w Edmonton jako stypendystka programu „Mobilność Plus” MNiSW, z czego cztery miesiące spędziłam w Edmonton, a dwa w Toronto wśród tamtejszej społeczności osób pochodzenia ukraińskiego z Polski, które przybyły do Kanady w latach 80. W 2015 r. otrzymałam stypendium Petro Jacyk Program for the Study of Ukraine w Centre for Russian and East European Studies w University of Toronto, które pozwoliło mi na kontynuację badań w Toronto, a w 2016 r. dzięki stypendium Canadian Institute of Ukrainian Studies ponownie odwiedziłam Edmonton i Toronto. $\mathrm{W}$ tym czasie przeprowadziłam prawie 100 wywiadów swobodnych i narracyjnych (w języku polskim i ukraińskim) z Ukraińcami przybyłymi do Kanady w latach 80. oraz zgromadziłam bogaty materiał z obserwacji. Dodatkowo przeprowadziłam kilka wywiadów w języku ukraińskim z dipisami przybyłymi do Edmonton pod koniec lat 40. oraz Ukraińcami urodzonymi w Kanadzie, przedstawicielami kolejnych pokoleń osadników z Galicji i Bukowiny. O części jedynie zasygnalizowanych tu spraw szerzej piszę w innych miejscach (Trzeszczyńska 2014; 2016a; 2016b; 2017). 
lu przypadkach uruchomił także mechanizm konfrontacji z własnym wyposażeniem kulturowym, ukrywaną lub wypieraną ukraińską identyfikacją narodową i pozwolił ją nie tylko dowartościować, ale wręcz osiągnąć dumę z pochodzenia i uczynić je podstawą kulturowej autoprezentacji.

Równocześnie biograficzne umocowanie w Polsce i silne do dzisiaj związki z krajem wciąż sytuują ich „pomiędzy”. Owe związki to nie tylko transnarodowe kontakty i więzi, ale także codzienne rutynowe praktyki: korzystanie z "polskiego" internetu, zakup kiełbasy w sklepie „Wisła Deli” i wizyta w klubie „Fregata”, czytanie „Polityki” i książek Olgi Tokarczuk. Moi współpracownicy uczestniczą w życiu społeczności polskich w Kanadzie, mają żony Polki/mężów Polaków i przyjaciół, którzy nie mają żadnych ukraińskich korzeni, a czasem otwarcie manifestują polski patriotyzm i „polski punkt widzenia” na dzieje polsko-ukraińskiego konfliktu lat 1943-1947². Materiał, który zgromadziłam, wskazuje, że substancjalne skupienie na granicach grup narodowych i odrębności poszczególnych diaspor może w tym wypadku zaciemnić obraz. Czy Ukraińcy z Polski identyfikują się z diasporą ukraińską? Czy wyłącznie? Czy są częścią „Polonii”? Jaki jest ich stosunek do kraju urodzenia i do Ukrainy? Będę się tu starała odpowiedzieć na te pytania oraz rozważę problem „osobności” pamięci Ukraińców z Polski w Kanadzie i strategii radzenia sobie z traumą wysiedleń, którą „przywieźli” z sobą do Kanady.

Lokalna historia Ukraińców w Polsce stanowi zasób wyłącznie imigrantów z Polski. Diasporyczne dyskursy o przeszłości narodu i państwa ukraińskiego oparte są na zupełnie innych treściach. Z kolei osoby ukraińskiego pochodzenia, urodzone w Polsce, sięgając po nawiązania do przeszłości swych przodków w II RP i PRL oraz do doświadczeń swojego pokolenia, konstruują swe symboliczne granice grupowe, oddzielające je od pozostałych członków diaspory: potomków osadników z Galicji i Bukowiny, dipisów oraz migrantów z niepodległej Ukrainy.

2 Napięcie i poczucie przymusu udziału w dyskusjach o „ukraińskich winach”, zbrodni wołyńskiej, stosunkach polsko-ukraińskich, UPA i akcji „Wisła” jest wyczuwalne zawsze, kiedy pojawia się zderzenie wyobrażonej „polskości” i „ukraińskości”. Spotykałam się z tym w terenie wielokrotnie, doświadczyłam tego także często na własnej skórze, kiedy przedstawiciele interesującego mnie środowiska komentowali moją działalność słowami „Polka i zajmuje się ukraińskimi dziejami!” (z niedowierzaniem), „nie są to sprawy łatwe, ale mimo że jesteś Polką, to można $\mathrm{z}$ tobą rozmawiać". Ponadto niektórzy moi współpracownicy formułowali wprost przekonanie, że wciąż czują się „wywoływani do tablicy” przez miejscowe środowiska polskie, w tym organizacje skupiające byłych kresowian, że odczuwają stale presję konieczności brania udziału w dyskusjach o relacjach obu narodów, choćby sami mieli własną tożsamość mocno spluralizowaną i płynną. Szerzej o tej swoistej kulturowej konieczności ustosunkowywania się do przeszłości piszę w przygotowywanej monografii pod tytułem Diaspora - pamięć - miejsca. Ukraincy z Polski z lat 80. XX wieku w Kanadzie. Studium etnograficzne. 


\section{Diaspory, ojczyzny i pamięci}

Badania nad grupą Ukraińców pochodzących z Polski wymagają przyjęcia postawy kosmopolityzmu metodologicznego ${ }^{3}$, który, jak przekonuje Ulrich Beck (2004: 136), stanowi szansę na pełniejsze dostrzeżenie złożoności badanych zjawisk, nie eksponuje bowiem narodowego punktu widzenia. Badacz zajmujący się diasporami musi unikać ich reifikowania, które wpędza w pułapkę myślenia o badanych grupach jako homogenicznych, trwałych, kolektywnych aktorach, a o ich członkach jako o połączonych wspólnymi wartościami, poglądami, wyobrażeniami i wspomnieniami. Konsekwencje używania pojęcia „diaspora” są rozmaite i nieobojętne, zarówno w dyskursie naukowym, publicystycznym, jak i w życiu samej społeczności, która siebie tak określa. Co więcej, członkowie poszczególnych diaspor wykazują się zróżnicowanymi postawami względem samej diaspory, innych społeczności funkcjonujących w tym samym społeczeństwie oraz wobec kraju pochodzenia. Z tego też między innymi powodu pojęcie "diaspora” oraz dominująca dziś w studiach nad migracjami perspektywa transnacjonalizmu wymagają szczególnej teoretycznej i metodologicznej czujności oraz sceptycyzmu względem ich popularności, także na gruncie antropologii społeczno-kulturowej. Będę się do niej odnosić jedynie punktowo.

Mając na względzie zalecenie Becka, piszę tu o Polsce i figurze „polskości” raczej jako o zbiorze idei i wyobrażeń niż esencjalistycznie rozumianym państwie narodowym. Zamiast o „ojczyźnie” wolę mówić o „kraju rodzinnym” bądź „starym kraju", aby nie narzucać skojarzeń $\mathrm{z}$ ideologiczną ojczyzną w rozumieniu Stanisława Ossowskiego (1967). Jak dowodzi mój materiał, Polska bowiem niekoniecznie jest ojczyzną Ukraińców z Polski, jest natomiast niewątpliwie krajem rodzinnym, rozumianym neutralnie jako miejsce urodzenia, miejsce, w którym się wyrosło, oraz gdzie żyją / pochowani są krewni. Podlega więc procesom negocjowania i kontestowania identyfikacji, jest obiektem przywiązania lub odrzucenia, łącznikiem w kontaktach z miejscowymi Polakami czy też "przeszkodą” w integracji z „resztą” diaspory ukraińskiej albo dla emocjonalnej tęsknoty za idealną, wyśnioną Ukrainą.

James Clifford zwraca uwagę, że nie sposób jednoznacznie ustalić definicji diaspory poprzez odwołanie się do kluczowych cech, które powinna posiadać. W zamian zaleca obserwację luźno powiązanych konstelacji praktyk wypracowanych w toku zamieszkiwania w rozproszeniu (Clifford 1994: 51). Wedle Stevena Vertoveca diaspory charakteryzują się powiązaniem trzech elementów: przyjmującymi zbiorową tożsamość grupami etnicznymi żyjącymi w rozproszeniu, osadzeniem $\mathrm{w}$ terytorialnych kontekstach i państwach oraz państwami i środowiskami, z których ich członkowie się wywodzą (2012: 5). Równocześnie przy takich ramach

3 Kosmopolityzm metodologiczny stanowi przeciwieństwo nacjonalizmu metodologicznego (Wimmer, Glick Schiller 2002). 
rozpatrywania diaspory zauważa on groźbę popadnięcia w metodologiczny nacjonalizm, polegający na uznaniu państwa, narodu, społeczeństwa i grupy etnicznej za naturalne formy współczesnego świata, przy konieczności uwzględnienia, że państwa narodowe nadal kształtują transnarodowość migrantów (Vertovec 2012: 22). Problem esencjalizujących właściwości pojęcia i koncepcji diaspory i pochodnych zwrócił także uwagę polskich badaczy, w tym antropologa Aleksandra Poserna-Zielińskiego (2011). Zauważa on, że pojęcia takie jak „wspólnoty etniczne”, „mniejszości etniczne”, „grupy imigracyjne” coraz częściej zastępowane są przez „diaspory”, a studia etniczne ewoluują w kierunku studiów nad środowiskami diasporowymi (Posern-Zieliński 2011: 23). Ponadto Posern-Zieliński zwraca także uwagę na nieporozumienia wynikające ze zbyt szerokiego traktowania środowisk polonijnych i uznawania ich za „jedną" diasporę. W ten sposób włącza się do niej Polaków zamieszkujących czasowo poza krajem, imigrantów oraz osoby, których przodkowie sprzed kilku pokoleń wyemigrowali z Polski (Posern-Zieliński 2011:24). Problem ten może dotyczyć innych podobnych wspólnot etnicznych, których historia osadnictwa na nowej ziemi liczy wiele dziesiątek lat i które to wspólnoty zasilane były kolejnymi falami migracyjnymi, jak na przykład Ukraińcy w Kanadzie.

Podobnie na problem esencjalizmu w studiach nad diasporą zwrócił uwagę niemiecki antropolog Martin Sökefeld (2006). Jego zdaniem badacze powinni pytać o to, jak, dlaczego, przez kogo i w jakim celu esencjalizowane są tożsamości, mając na względzie to, że tożsamości stają się „politycznie efektywne” tylko wtedy, kiedy są wykorzystywane i popierane przez pewną grupę ludzi, którą ktoś lub coś mobilizuje. W związku z tym definiuje on diaspory jako wyobrażone transnarodowe wspólnoty, które jednoczą ludzi żyjących w odseparowanych lokalizacjach, opartych na „obiektywnych” i „subiektywnych” kryteriach, które diaspora musi spełniać, aby być skategoryzowana jako diaspora. Rozumienie diaspory jako wyobrażonej transnarodowej wspólnoty nie zakłada automatycznie dużej częstotliwości transnarodowych kontaktów. Transnarodowość może być „czysto wyobrażeniowa i symboliczna”. Co więcej, uznanie, że różne są wymiary, idee i wyobrażenia wspólnoty w diasporze, pozwala określić jako jej członków także tych, których wyobrażenia nie są identyczne (Sökefeld 2006: 265-272). Koncepcja potrzeby reprodukcji wyobrażeń wspólnot diasporowych jest sposobem na uniknięcie zabiegu esencjalizowania, ponieważ uznajemy, że diaspory nie są po prostu dane i stałe, ale muszą być stale i wciąż odnawiane przez agentów sięgających po różnorakie środki mobilizacji. Trzeba mieć także świadomość, że z kolei rezultaty tych zabiegów, czyli dyskursy diasporowe, konstruują diasporę i tożsamość jako zesencjalizowane pojęcia, co może być jednak bardzo efektywne dla diaspory w kwestii społecznego i politycznego uznania, i w równie esencjalizujący sposób wiążą ją z miejscem, „ojczyzną” (Sökefeld 2006: 279). Tymczasem ów związek może być nieoczywisty, co doskonale pokazuje mój przykład. 
Z konceptualizowaniem diaspory jako wyobrażonej transnarodowej wspólnoty znakomicie koresponduje i uzupełnia je propozycja Rogersa Brubakera, wedle którego diasporę należy widzieć jako wiązkę postaw, idiomów, projektów i praktyk (2005). Daje to możliwość studiowania stopnia poparcia i zaangażowania w diasporowy projekt, budowania przez jednostki postawy diasporowej i prześledzenia stopnia i wymiarów utożsamienia badanych z diasporą.

Diasporowe praktyki, wyobrażenia, idiomy, projekty i postawy zasila między innymi pamięć. W sytuacji migracji zmieniają się status i znaczenie miejsca, dlatego współczesne teorie pamięci, lokujące ją in situ, w stabilnym, niezmiennym środowisku, są nieadekwatne do badania pamięci migrantów (Creet 2011: 3-5). Kanadyjska badaczka Julia Creet zwraca uwagę, że pamięć w diasporze oraz jej relacja do faktu migracji pozostają słabo rozpoznane. Klasycy studiów nad pamięcią, Maurice Halbwachs i Pierre Nora, sytuowali pamięć w miejscu, któremu jest przypisana, a które to miejsce znika wraz z migracją. Wszystkie współcześnie modne europejskie koncepcje pamięci, łącznie z bardzo wpływową teorią pamięci kulturowej i komunikatywnej Jana i Aleidy Assmannów, narodziły się na bazie studiów nad pamięcią o II wojnie światowej i powojenną kondycją/traumą oraz jako pochodna tradycyjnego formatu studiów, zanurzonego w związek z państwem narodowym, kategorią narodu i obywatelstwa (Creet 2011: 17). Europejskie koncepcje pamięci kulturowej muszą zatem zostać zrewidowane na podstawie materiału $\mathrm{z}$ diaspory. Autorka proponuje rozpatrywanie dynamiki i mobilności pamięci oraz uznanie, że „podąża” ona za migrantami, przekraczając terytoria (Creet 2011: 10). Szczególnie interesującym laboratorium wydaje mi się w tym kontekście diaspora $\mathrm{w}$ diasporze, grupa nieodwołująca się do państwa narodowego w klasycznym rozumieniu, taka jak badana przeze mnie grupa Ukraińców z Polski. Miejsce, które pojawia się w pamięci, nie musi dłużej istnieć, stanowi jednak zwornik i punkt odniesienia dla wszystkich innych miejsc, które stają się ważne dla wspomnień.

\section{„My jesteśmy ni pies, ni wydra”. 0 byciu „pomiędzy”}

Aby zrozumieć, z jakimi diasporowymi dyskursami i projektami mają do czynienia osoby ukraińskiego pochodzenia urodzone w Polsce i mieszkające od lat 80 . w Kanadzie, niezbędne jest przynajmniej skrótowe naszkicowanie kontekstu historycznego ukraińskiej diaspory w tym kraju. Historia diaspory ukraińskiej w Kanadzie sięga końca XIX wieku, kiedy to rozpoczęła się akcja osadnicza na preriach Alberty i Manitoby. Obok innych imigrantów przybywali tam Rusini/ Ukraińcy z Galicji i Bukowiny, znajdujących się w granicach Austro-Węgier, oraz z Imperium Rosyjskiego. Mieli oni zasiedlić bezkresne prerie i uprawiać ziemię. Na początku XX wieku natomiast przyciągały imigrantów ośrodki przemysłowe na wschodzie Kanady. W latach międzywojennych granice powstałego w roku 1922 Związku Radzieckiego były dla Ukraińców nieprzekraczalne, do Kanady 
przybywali tylko ci, którzy zamieszkiwali Polskę (Martynowych 1991). Wyjątek stanowili nieliczni uciekinierzy z głodującej części radzieckiej Ukrainy w czasie hekatomby Hołodomoru.

Powojenna Kanada przyjęła osoby, tak zwane displaced persons (dipisów), które koniec II wojny światowej zastał w niemieckich obozach koncentracyjnych i które znalazły się w brytyjskiej strefie okupacyjnej (Luciuk 2000). Była to liczna i aktywna grupa, która wkrótce zasiliła instytucje społeczne i naukowe ukraińskiej diaspory, pracując nad kształtem oficjalnej pamięci ukraińskiej diaspory w Kanadzie. Projekt pamięci opierał się odtąd na węzłowych punktach w dziejach narodu i państwowości ukraińskiej, takich jak ukraiński ruch niepodległościowy, Hetmanat, Ukraińska Republika Ludowa, Zachodnioukraińska Republika Ludowa, prześladowania i terror w ZSRR (Wielki Głód, czystki 1937 r.), działalność OUN i UPA, dywizja SS Galizien (por. np. Hrycak 2000). Służyły one za podstawę dyskursów autoprezentacyjnych na forum społeczeństwa kanadyjskiego oraz na własne, diasporowe potrzeby.

To właśnie pokolenie dipisów przyjmowało i sponsorowało przyjazd młodych Ukraińców z Polski. Wyjeżdżali oni w wieku 18-30 lat, po szkole średniej lub studiach, nierzadko wraz z małżonkami i małymi dziećmi. Najczęściej decydowali się na „pielgrzymkę” do Watykanu lub „wycieczkę” do RFN albo innego zachodniego państwa i trafiali do przejściowych obozów dla uchodźców z krajów socjalistycznych. Spędzali tam zwykle kilka miesięcy, zanim dostawali się jako uchodźcy polityczni do Kanady. Na miejscu mieli zapewnione mieszkanie, kurs językowy i zasiłek (opłacane przez państwo) lub gościli ich w swoich domach dipisi. Do czasu usamodzielnienia się w Kanadzie (zwykle przez rok) korzystali z opieki i wsparcia członków diaspory, z nimi też spędzali wolny czas, zarówno w domach, jak i w siedzibach diasporowych instytucji. Siłą rzeczy podczas tych spotkań i udziału w ukraińskich imprezach kulturalnych konfrontowali swoje wyobrażenia o życiu diaspory w Kanadzie i wiedzę o przeszłości narodu ukraińskiego z zastanymi na miejscu dyskursami. Trzeba pamiętać, że poza tymi, którzy byli aktywnymi działaczami w Polsce, ukończyli ukraińskie liceum ogólnokształcące lub filologię ukraińską, albo tymi, którzy sami poszukiwali informacji i dużo czytali o historii Ukrainy, reszta młodych imigrantów nie miała głębszego przygotowania w tym zakresie. Przybyli za to wyposażeni w pamięć lokalną o dziejach Ukraińców w Polsce - pamięć o rodzinnej i wspólnotowej traumie wysiedleń z lat 1944-1947, o walce o wolną Ukrainę w szeregach UPA, wyrokach, więzieniu i konieczności ukrywania przeszłości członków swych rodzin i kręgów sąsiedzko-towarzyskich, o prześladowaniach i ogólnie „mniejszych szansach” dla Ukraińców w Polsce przedwojennej, a także z własnymi, pokoleniowymi doświadczeniami dyskryminacji, kłopotów z tożsamością, podwójnego życia - oficjalnie Polaka, a w domowym zaciszu Ukraińca i tak dalej. Zetknięcie z ukształtowaną przez diasporowe instytucje wizją dziejów Ukraińców oznaczało nie tylko poszerzenie perspektywy i asumpt do refleksji nad własnymi korzeniami. Niekiedy dopiero w Kanadzie 
wielu imigrantów poznało niektóre aspekty historii ukraińskiej, jak Wielki Głód lat 1932-1933. Z kolei dla członków diaspory ukraińskiej niezrozumiałe i nieczytelne pozostawały ich doświadczenia dorastania w PRL-u i przeżycia ich rodziców czy dziadków - wysiedlenia, więzienie, pogrzebanie marzeń o wolnej Ukrainie, zniszczenie dotychczasowego świata i rozdzielenie wspólnot wioskowych. Owo niezrozumienie spowodowało stopniowe izolowanie powojennych dziejów Ukraińców w Polsce i zamykanie pamięci o nich w kręgach rodzinno-towarzyskich, składających się z takich samych imigrantów z Polski. W takich przestrzeniach wspominano młodość, rzadziej wracano do przeżyć poprzednich pokoleń.

Po 1991 roku zaczęli napływać do Kanady migranci z niepodległej Ukrainy ${ }^{4}$. Środowiska ukraińskie w Kanadzie są więc niezmiernie zróżnicowane: to potomkowie pionierów, robotników, dipisów i imigrantów zza żelaznej kurtyny. Łączą ich przede wszystkim praktyki autoprezentacyjne podejmowane na użytek samej diaspory, ale także skierowane na zewnątrz, w stronę innych wspólnot, składających się na kanadyjskie społeczeństwo. Praktyki te opierają się na stałym i niezmiennym od dziesięcioleci zestawie środków, figur i dyskursów: historia Ukrainy i narodu ukraińskiego (przede wszystkim Wielki Głód i współczesne przełomy: pomarańczowa rewolucja, rewolucja godności 2013/2014 wraz z ofiarami - Niebiańską Sotnią), diasporowy folkloryzm (tańce, stroje i pieśni), haftowane koszule (soroczki) i wyimki z kuchni ukraińskiej (pierogi, gołąbki i barszcz) - traktowane jako znaki ukraińskiej kultury. Chodzi o wywołanie skojarzenia, posłużenie się popularnymi i powszechnie znanymi w społeczeństwie kanadyjskim symbolami, które mają zamarkować teren autoprezentacji, wskazać na symboliczne panowanie Ukraińców w danym miejscu i czasie, uwiarygodnić reprezentację wyobrażonej „ukraińskości”. Pojawia się tu jednak groźba reprodukowania stereotypów, powtarzania utartych wyobrażeń, które zarówno sami przedstawiciele diaspory, jak i inni mają na ich temat, sprowadzania siebie do czytelnych znaków egzotyki, która jest atrakcyjna i pożądana w kanadyjskim otoczeniu.

W tym samym czasie co Ukraińcy, wyjeżdżali do Kanady także Polacy. Ich sąsiedztwo w Kanadzie stanowi ważny punkt odniesienia i stale aktualizuje pytania o przeszłość i miejsce Polski w prywatnej skali miejsc znaczących. Wielu moich rozmówców ma żonę Polkę czy męża Polaka, niemal wszyscy wciąż posługują się językiem polskim i z "polskiego" internetu dowiadują się o tym, co się w kraju dzieje. Robią zakupy w polskich sklepach, a kiedy przyjedzie z polski kabaret czy piosenkarka, idą do polskiego klubu. Wielokrotnie zapewniano mnie, że są to oczywiste wybory, podyktowane bliskością kulturową, sentymentem, poczuciem swojskości czy przywiązaniem do przeszłości.

4 To właśnie imigranci z Ukrainy stanowią obecnie dla członków interesującej mnie grupy najważniejszy punkt odniesienia. Pokolenie dipisów już odchodzi. Z kolei przybysze z niepodległej Ukrainy wnieśli nowe problemy: dziedzictwo przymusowej sowietyzacji w latach ZSRR i język rosyjski jako język komunikacji. 
Są jednak takie obszary, które sytuują ich w wyraźnej kontrze wobec miejscowych Polaków i wobec Polski rozumianej tu jako „racja stanu”, wizja stosunków polsko-ukraińskich. To pamięć o przeżyciach rodziców i dziadków oraz współczesne dyskusje na temat zbrodni UPA na Wołyniu. Szczególnie ta ostatnia kwestia budzi emocje. Co kilka lat na zaproszenie organizacji polonijnych przyjeżdża do Kanady ksiądz Tadeusz Isakowicz-Zaleski, który uznawany jest za eksperta. Dla przeciwwagi, aby podjąć dyskusję z polskimi środowiskami, w których dominuje jednostronny przekaz, kilku aktywnych działaczy z grona Ukraińców z Polski postanowiło wydać po polsku książkę Druga wojna polsko-ukraińska (1942-1947) Wołodymyra Wiatrowycza, ukraińskiego historyka specjalizującego się w badaniu zbrodni wołyńskiej. Zdobyli fundusze na publikację, wykonali profesjonalne tłumaczenie na język polski i chcieli zaprezentować książkę w Toronto. Plan ten jednak się nie powiódł. Jak opowiadał mi Andrzej5:

To taki wkład jakiś był w tą całą, chociaż jakieś, no wprowadzenie jakiejś jeszcze innej, innej myśli na to z naszej strony, ale nawet jak żeśmy robili prezentację książki, nie? Ja mówię, proponuję, mówię słuchajcie, weźcie zrobimy może tą prezentację tej książki, czy tego tłumaczenia książki, nie? Tutaj w Kanadzie, w jakiś sposób taki, żeby zaprosić polskie środowisko, nie? Organizacje, może konsulat i tak dalej, prasę polską. No ta propozycja, z początku się zastanawiali nad tym, później została odrzucona, bo się bardzo bali tych krzykaczy, że przyjdą i zepsują wieczór, zaczną tam swoje te robić, i to nie przeszło, nie odważyli się na to. (...) Słyszeli, jakie tam wychodziły opinie, takie emocjonalne, ze środowiska, i nie chcieli tego u siebie mieć na spotkaniu (M/52/2014T/9).

Poznałam wiele osób, które poszukują także innych dróg kontaktu ze współczesną Polską niż na miejscu w Kanadzie. Niektórzy starają się odwiedzać miejsca, w których spędzili młodość, decydując się jak najczęściej, niemalże co roku, właśnie w Polsce spędzić urlop. Charakterystyczne jest, że miejsca, skąd pochodzili rodzice i dziadkowie, miejsca w południowo-wschodniej Polsce są ważne na poziomie deklaratywnym, ale się ich nie odwiedza. Taka potrzeba dotyczy miasteczek i miast, w których spędziło się dzieciństwo i młodość, dokąd przodkowie zostali wywiezieni w 1947 roku i gdzie przyszło im żyć. Poza odwiedzinami u bliższej i dalszej rodziny (coraz częściej na cmentarzach) ruszają oni w podróż po miejscach, w których toczyło się ich życie, zanim wyjechali do Kanady. Są to miejsca, które po latach mają największą moc przyciągania i w których oglądają zmiany, jakie przyniosła transformacja ustrojowa i przemiany obyczajowe. Wśród tych ostatnich najważniejszy jest stosunek do języka ukraińskiego na polskich ulicach:

Ja myślę, że, ja wracam do Polski, jakbym do domu wracała. No tam się urodziłam, tam spędziłam 35 lat, to jak można się odciąć od na przykład od miejsca, gdzie jest się urodzonym? Nie ma czasami znaczenia, jakiej narodowości jest, ale też jestem urodzona na Ziemiach Odzyskanych, gdzie moi dziadkowie i moja mama, i ojciec nie są urodzeni, tak, ale mnie tam ciągnie. (...) Jeź-

5 Imiona zostały zmienione. Przy cytatach stosuję następującą sygnaturę: płeć / przybliżony lub dokładny wiek / rok i miejsce rozmowy (Toronto, Edmonton) / numer wywiadu. 
dzimy co roku. Tak co dwa lata, albo co rok. To już, z przyjemnością jedziemy, my sobie rozmawiamy po ukraińsku na przykład z Jurkiem, oni [Polacy] sobie rozmawiają po polsku i nie mamy żadnego problemu. Nikt nic nam nie zwraca uwagi, nikt się nie patrzy, po prostu wydaje mi się tolerancja jest inna troszkę, tak, bo kiedyś może, w czasach kiedy ja dorastałam, może w tym czasie troszkę było też troszkę, polityka w takim sensie była, że, no niesprawiedliwa czasami dla niektórych ludzi. (...) Tak że nie mam absolutnie żadnych tam problemów, jak jadę, i wracam jak do siebie do domu (K/60/2014E/2).

Przywożą stamtąd pamiątki, książki i filmy. Niektórzy mają pokaźne biblioteczki, stale coś z Polski zamawiają, proszą krewnych o przysłanie. W biblioteczce Edyty, która zajmuje cały basement jej domu w Toronto, podziwiałam bieżące nowości wydawnicze z Wydawnictwa "Czarne” i Literackiego (swoją drogą rozmowy o literaturze były ważną częścią naszych spotkań). Rozmowa o książkach Janka naświetliła jego stosunek do kraju rodzinnego, ale też pokazała pewne rozdarcie, które odczuwa jako Łemko o tożsamości ukraińskiej, bardzo przywiązany do Polski, otaczający się rzeczami przywiezionymi z każdej do niej podróży, a równocześnie mocno zakorzeniony w Kanadzie i wdzięczny temu krajowi za dystans i perspektywę oglądu samego siebie. Stojąc przy wielkim regale, w całości wypełnionym polskimi książkami i filmami, wyjaśniał mi:

Ja jestem tym, kim ja jestem, nie? (...) Ja to czytam, ja jestem na bieżąco z tym. Może jestem bardziej czasami, myślę, i nie chcę się tym chwalić, ale czasami myślę, że jestem dużo bardziej, jak niektórzy ludzie, którzy są w moim wieku, nie? Że... No chodź, pokażę ci, że się chwalę w tym momencie.

Ale wiesz, ja próbuję zrozumieć, na czym to polega.

Zobaczyłaś Ranczo, zobaczyłaś... [rozbawienie] No takie rzeczy, nie? Czy ty rozumiesz, że Polska dla mnie jest ojczyzną też? I ja nie uważam siebie... Szachy z Krakowa. Mówisz o Krakowie. To są szachy z Krakowa. [śmiech]

I w jakiś sposób to mi wytłumaczy pewne rzeczy. Po prostu ja kocham. Czy ty rozumiesz, że ja kocham Polskę jako... Ja czuję się Łemkiem, czuję się... Byłem... W tym momencie muszę ci powiedzieć, że byłem czasami obrażany, bo byłem obrażany przez kolegów Polaków, nawet jak byłem na studiach, zupełnie w ogóle niepotrzebnie wyzywany byłem od Ukraińców, co było takie... Ale ja uważam, że ci ludzie po prostu nie wiedzieli, kim oni są, i to wszystko. Ale zobacz, moje książki. Przecież ja mam polską literaturę, ja mam...

To jest dla mnie niezwykłe, naprawdę.

Dlaczego? Ja ci chcę pokazać, że nie zawsze Łemek jest Łemek. Ja jestem, kim ja jestem, nie?

$W$ takim razie jakim jest miejscem Kanada $w$ tym wszystkim?

Kanada pozwala mi otworzyć oczy na pewne rzeczy. Widzisz, ja nie robię tego dla mego syna czy... Ja robię to, co tu widzisz, to jest moje. To nikt tego mi nie zabierze, nikt mi tego nie odda, a Kanada jako taka, widzisz... Ja mogę z tobą dzisiaj, mogę gościć cię w moim domu, możemy mieć normalną rozmowę, ty nie patrzysz na mnie, że ja jestem banderowiec czy ktoś inny, nie? Rozumiesz, co chcę ci powiedzieć? Po prostu mnie traktujesz normalnie, jako człowieka. I to wszystko, co ja chcę, i to, co Kanada mi daje do tej pory (M/56/2014E/5).

To w Kanadzie Janek doświadczył „normalności” i dopiero tam etykietka Ukraińca przestała mu ciążyć. Kanada to miejsce, gdzie można być pogodzonym z całym konglomeratem różnych identyfikacji i tożsamościowych „ciągot”, które w sobie odkrył i które pozwalają mu być w pełni sobą. Ale to dopiero tam i po wie- 
lu latach przychodzi refleksja o miejscu i znaczeniu kraju rodzinnego oraz odbytej tam socjalizacji, edukacji, stawaniu się tam osobą dorosłą:

Mam moją wojskową czapkę tutaj, wszyscy na mnie patrzyli, ja chciałem pokazać, że jestem z Polski. Ja nie chciałem ukrywać, skąd ja jestem, się ludzie dziwili, tu jest pełno zdjęć. Trzymam ukraińską flagę, polską flagę, w domu mam cztery, kanadyjską, amerykańską, to są nasze rodzinne, ja się tego nie wstydzę, ja jestem dumny właśnie z tego, ja byłem też członkiem Solidarności (...). Pani musi zrozumieć, że związek psychiczno-geograficzny jest bardziej z Polską niż z Ukrainą. (...) Dlatego mnie to, mnie to cały czas nurtuje, bo ja mówię, że jestem Polakiem. Żyłem tam 27 lat. Ja jestem Kanadyjczykiem, żyję tu 25 lat, ale sercem bardzo mi blisko wszystko ukraińskie, jestem Ukraińcem, ja naprawdę tak czuję. Ja nie wiem, jaką mową myślę niekiedy (M/53/2014E/7).

Paradoksalnie dopiero któryś z kolei powrót z Polski do Kanady po spędzonym urlopie pozwolił na odwrócenie perspektywy. Wiesi siedem lat zajęło dochodzenie do wniosku, że wraca do Kanady jak do domu, że wyjeżdża z miejsca, które już nie jest domem. Podobnie opowiadał Adam, który odkrył, że choć w Polsce wciąż czuje się u siebie, najbliższa jest mu właśnie Kanada. Dopiero jednak z upływem lat to miejsce stało się bliskie: „po kolejnym przyjeździe do Kanady uświadomiłem sobie, że ja wracam do domu, [do miejsca] gdzie urodziły się moje dzieci" (Adam).

Niezwykle ciekawa jest też relacja ze współczesną, niepodległą Ukrainą. Przypomnę, że osoby ukraińskiego pochodzenia wyjechały z Polski, zanim powstało niezależne państwo. Postawy wobec tego kraju można podzielić na dwa typy: wybór Ukrainy jako ojczyzny ideologicznej, której los jest bliski sercu, albo wskazanie na obcość tego państwa. Jednak nawet ci, którzy wyraźnie odcinali się od Polski, oceniają Ukrainę pragmatycznie i trzeźwo, sięgając po argumenty ekonomiczne, estetyczne lub zwracając uwagę na korupcję, jak w wypowiedzi Jurija:

ja przyznam się pani szczerze, że mi Ukraina jest bliższa jak Polska. Okej, może dlatego, że ja weszłem tak w środowisko...

O to chciałam zapytać.

Może dlatego, że weszliśmy tak głęboko w te środowisko, w tą kulturę, bardzo dużo znajomych, czy, powiedzmy sobie, w Kijowie w teatrze, czy we Lwowie, tam główny reżyser i tak dalej, te wszystkie friendy i inni ludzie na Facebook powiedzmy. Ja mam bardzo dużo znajomych poetów, piśmienniki, żurnalistów i tak dalej z TV i to są moje friendy wszystkie, i może dlatego, jak ja bym miał wracać, ja bym do Polski nie jechał.

A na Ukrainę?

Na Ukrainę bym pojechał, ale tam póki co, nie to dlatego, że się boję, że wojna, po prostu nie wiem, jak to się wszystko skończy raz. Drugi raz, że jechać tam, trzeba tu do pensji dołożyć. [śmiech] Bo tam jeszcze korupcji za dużo jest (M/59/2015T/46).

Z kolei Wiesia wskazuje na tożsamościowy dyskomfort, jaki fundują jej w Kanadzie migranci z Ukrainy, którzy przypisują jej i innym Ukraińcom z Polski etykietkę „Polaka”, budowaną na założeniu, że „z Polski” oznacza „Polak”. 
Ja nawet nigdy nie myślałam, wprawdzie na przykład, no możliwości, na przykład, że można mieć taką możliwość, że ja bym mogła mieszkać na Ukrainie. Nigdy na przykład taka myśl do mnie i nawet teraz, bo bardzo dużo ludzi wyjeżdża, na przykład mają ci, nawet którzy są z Polski Ukraińcy, mają na przykład mieszkanie na Ukrainie i jeżdżą...

\section{Poważnie?}

Tak. Ale nigdy mi taka myśl, jakoś mi, nie wiem, nie myślałam o tym. Nie przeszło mi nawet przez głowę, żeby na Ukrainę, bo powinna mi Ukraina być bliska sercu, jest mi bliska sercu, ale po prostu w tym samym czasie, mi się wydaje, że troszkę i daleka. A dlaczego też, bo tu jest też mała rola dyskryminacji, bo ci z Ukrainy mówią, że na przykład na nas, dlatego, że my troszkę już działamy społecznie i tak dalej, mówią, a, mówią na nas „Polacy” (K/60/2014E/2).

Wiesia odczuwa owo etykietowanie jako dyskryminację, która skutecznie zniechęca ją do rozpatrywania Ukrainy jako potencjalnego domu, a zatem miejsca swojskiego, gdzie można być w pełni i naprawdę sobą. Takim miejscem dla niej jest wyłącznie Polska i w pewnym stopniu Kanada.

\section{Pamięć}

Osoby ukraińskiego pochodzenia przybyłe z Polski nie tylko przy okazji świąt i festiwali ukraińskich konfrontują się z diasporowymi dyskursami o przeszłości. Również w codziennych praktykach, podczas zwykłych spotkań konstruują oni i podkreślają swoją odrębność wobec starszych fal ukraińskiej imigracji oraz wobec Ukraińców z Ukrainy, a służy im do tego pamięć dziejów tej grupy w Polsce i dialekt języka ukraińskiego z Polski. Istotne jest także to, że pamięć ta dotyczy niemal wyłącznie powojennych dziejów Ukraińców w Polsce, co w praktyce oznacza wysiedlenia w ramach akcji „Wisła” i ich konsekwencje. Rzadko jednak miałam do czynienia w terenie z szerszą refleksją na ten temat. Nawet najbardziej otwarci i zaprzyjaźnieni rozmówcy zazwyczaj ograniczali się do stwierdzenia, że o wysiedleniach wiedzą, pamiętają i uważają je za istotny element rodzinnej historii. Niekiedy brak treści do narracji wynika $\mathrm{z}$ braku nasycenia opowieściami w rodzinnych domach:

A rodzice do tego wracali [do wysiedleń], mówili o tym, styszeliście od dzieciństwa?

Włodek: Niechętnie.

Gienia: Niechętnie.

Włodek: Nie, niechętnie. (...) No starsze pokolenie miało zakodowane, mój ojciec, mój dziadek podpisali, że nie przyznają się... Nie będą opowiadać tego po prostu już (K58, M61/2014T/15).

Od indywidualnych zainteresowań i poszukiwań zależy wiedza o przeszłości i teraźniejszości Ukraińców w Polsce. Zazwyczaj przywoływane są wysiedlenia, u niektórych jest to długa i nasycona szczegółami narracja o samych wysiedleniach i ich konsekwencjach, ale też perspektywa ta ma wymiar lokalny - ogra- 
nicza się do rodzinnych wspomnień i zasięgu własnej wsi, miasteczka, powiatu, rzadko przekraczając te granice w kierunku szerszych uogólnień.

No rusza. Tak, to rusza, bo to mimo wszystko w pamięci ono zostaje z opowiadań czy z tych publikacji, teraz, powiedzmy, z mego prywatnego boku, to babci brata zabili tam na, on był chory i go tam, jak ich wysiedlali, i on wrócił się z powrotem i to, co mnie babcia przekazywała, że jego tam na peczi zastrility. (...) Tak że to, no może to mnie tak personalnie nie ciąży na mnie czy coś, bo to już i czas i tak dalej, ale to w pamięci to zostaje, że to, ja myślę, że to niepotrzebne było, ale, ta akcja „Wisła”, no ale to tam ktoś inszy zarządził tym wszystkim i jakie tam było polityczne potrzeby, my mniej więcej orientujemy się, no ale, no szkoda tego wszystkiego. Bo mimo wszystko to zniszczyło się etniczną grupę, z głębokiej tradycji (M/59/2015T/46).

Tylko nieliczni wskazywali na silne emocje - lub okazywali je w trakcie rozmów - związane z przeżywaniem tej przeszłości we własnym życiu w Kanadzie. Jakie jest zatem miejsce akcji „Wisła” w pamięci i codzienności Ukraińców z Polski żyjących w Kanadzie? Wielu moich rozmówców zwraca uwagę na to, że jest to swoista symboliczna etykieta, za pomocą której pozycjonują się i definiują wobec pozostałych Ukraińców w Kanadzie. Dla niektórych jest to nie tylko wspomnienie rodziców czy dziadków, ale także ważna część osobistej tożsamości, indywidualnej biografii, która do dziś zmusza ich do namysłu nad swoim miejscem w świecie. Dla Andrzeja pamięć o wysiedleniach jest podstawą definicji Ukraińca z Polski - to taki Ukrainiec, który przeżył i przepracował w kolejnym pokoleniu akcję „Wisła” i jej skutki.

Mi się wydaje, że to jest pewna forma identyfikacji dla mnie, bo nieraz właśnie z Kanadyjczykami, oni się pytają, kto ty jesteś, nie? No ja siebie identyfikuję jako Ukrainiec z Polski, nie? A oni pytają się, jak i co, nie? Gdzie się urodziłeś, nie? Ja zaczynam opisywać, że urodziłem się a ziemiach zachodnich tam, nie? Pod granicą niemiecką, dalej nie mogą zrozumieć, skąd [Ukraińcy] się tam wzięli. Ja wtedy muszę zaczynać tłumaczyć tą historię, że mieszkali właśnie na tych i tych terenach i po wojnie, że była ta akcja przesiedleńcza i ta właściwie akcja „Wisła” jest pewną formą identyfikacji dla nas. (...) Dla nas to jest, jest tym wyznacznikiem naszego miejsca tutaj, kim my jesteśmy. Tak że to, to nie sprowadza się do okrągłych rocznic, nie? A więcej do identyfikacji siebie $\left(\mathrm{M} / 52 / 2014 \mathrm{~T} / 9^{6}\right)$.

Zwraca uwagę realny wpływ pamięci o wysiedleniach na tożsamość rozmówcy oraz przekonanie o takim wpływie na całą wspólnotę Ukraińców z Polski. Jednocześnie wysiedlenia i ich skutki służą do skonstruowania narracji o własnym pochodzeniu, miejscu urodzenia, są swoistym emblematem służącym autoprezentacji w Kanadzie. Dotyczy ona zarówno wewnątrzdiasporowych kontaktów, jak i relacji z innymi przedstawicielami kanadyjskiego społeczeństwa.

Postać Joanny to natomiast przykład dziedziczenia kolektywnej traumy. Jej pamięć o akcji „Wisła” ma bardzo prywatny charakter i jest słabo znarratywizowana. Jak mówiła, wysiedlenie w niej „siedzi”. Z emocjami opowiadała mi o podróżach do Polski, by „ładować baterie”, i że wysiedlenie do dziś ma na nią ogromny wpływ

${ }^{6}$ Kod ten należy rozumieć następująco: mężczyzna / lat 52 / rok badań / numer wywiadu. 
w postaci obciążenia psychologicznego, z którym musi się zmagać: jako Ukrainka z Polski, która nie mogła mówić otwarcie o tym, kim jest, i która przywiozła do Kanady strach, zahukanie i niepewność. Z czasem zdołała to zwalczyć, ale bardzo jej to utrudniało życie. I choć nareszcie jest wolna, to wciąż czuje to obciążenie.

Perspektywa Ani jest typowa dla osób, które uważają, że przeszłość ich przodków to sprawa zamknięta, mająca znaczenie dla świadków i ofiar, ale już nie dla nich.

Ania: Wiesz co, ja tylko o tym wiem, ale ja tego nie przeżywam. Dlatego bo ja jestem za młoda, żeby to przeżywać. Ja tylko, wiesz co, pamiętam, teraz mi się przypomniało, że moja babcia jeździła jeszcze w ich strony, bo tam był ten pomnik Świerczewskiego.

W Jabłonkach pod Baligrodem.

Ania: W Jabłonkach i ona przywiozła tą, i babcia tam kurczę była taka zła, i tam przeklinała sobie pod nosem. Ale ja, kurczę, nie wiedziałam, bo jeszcze byłam wtedy taki, kurczę, knypek i nie miałam pojęcia, o czym oni, kurczę, gadają. I tylko pamiętam tą wiz..., tą kartkę, taką wiesz, pocztową kartkę $\mathrm{z}$ tym pomnikiem i ten most jakiś tam. I ciągle tam coś tato gadał $\mathrm{z}$ babcią, ale ja, teraz dopiero do mnie to doszło po tylu latach, ale ja nie wiem dokładnie, o co oni, o czym oni tam się targowali.

Tomek: Ja osobiście...

Ania: Ale oni musieli być w tych czasach, jeszcze jak byłam mała, musiała być jednak w swoich stronach.

Tomek: $\mathrm{Z}$ tego powodu, gdybym ja mieszkał w Polsce, może ja bym jakieś tam robił starania, może bym kupił tą ziemię, którą tam, jakąś tego, nie. Ale z tego powodu, że to jest tak daleko, po prostu o tym się nie myśli (K49, M53/2014T/19).

Ani, która wyjechała z Polski w 1981 roku w wieku 16 lat, nie interesowała przeszłość rodziny. Zapamiętała tylko atmosferę rozmów i wrażenia, jakie miała babcia po powrocie z Bieszczadów. Podobnie jak ona, także inni podkreślali, że nie odczuwają żadnego wpływu wysiedleń na ich życie, a jeśli już, to wpływ pozytywny. Niektórzy mówili wprost o tym, że gdyby nie akcja „Wisła”, nie byłoby ich w Kanadzie i nie odnieśliby sukcesu życiowego, także materialnego. Koresponduje to często $\mathrm{z}$ formułowanym przez migrantów przekonaniem, z którym się wielokrotnie spotkałam, że rozproszenie Ukraińców na ziemiach zachodnich i północnych oznaczało modernizację i bolesną, niełatwą, ale jednak skuteczną drogę ku nowoczesności, z której oni jako kolejne pokolenie mogli w pełni skorzystać niekiedy nawet jeszcze w Polsce. Sławek i jego żona Maria mówili mi z emfazą, że gdyby nie wysiedlenia, nie skończyliby medycyny i nie mieliby możliwości, aby wyjechać do Kanady, a także odnieść sukces materialny.

Edyta od dziecka nasiąkała przeciwstawnymi obrazami i wspomnieniami dwóch babć:

Dziadkowie coś opowiadali o swoich dawnych stronach?

Opowiadali, no wiadomo. Na przykład jedna babcia, ta, która jest z Dobrzanki, powiedziała, że by w życiu nie chciała tam wrócić. Nie miała takiej tęsknoty nigdy, bo powiedziała, że tam była taka bieda, że, mówi, że dziękujcie Bogu, że nas wywieźli nie na Ukrainę, że nas stamtąd wywieźli, tylko że nas wywieźli do Niemiec, bo tu, mówi, takie niemieckie tereny, a z drugiej 
strony z kolei ta druga babcia, już tutaj ci, co byli dziadkowie z Woli, to zdecydowanie tęsknili i oni tam, wiadomo, jakie to wszystko było najpiękniejsze i sady, i wszystko, tak że opowiadali w ten sposób, że... No, i całe życie, no, wiadomo, no, i tą partyzantkę, i... Pół rodziny w lesie przesiedziało. Wiecie, jako to... [śmiech] (K/40/2014T/18).

Wielokrotnie, przy różnych spotkaniach, zwracała mi uwagę, że jest zmęczona martyrologią Ukraińców w Polsce i ciągłym eksploatowaniem kwestii wysiedleń w publicystyce oraz strategiach autoprezentacyjnych mniejszości ukraińskiej w Polsce, które wciąż śledzi. W kontekście kolejnej rocznicy zbrodni wołyńskiej, gestów polityków, przeprosin i porównywania doznanych krzywd mówiła $z$ irytacją: „Mam już dosyć przeprosin, chcę przestać być ciągle przepraszana i zmuszana do przeprosin. One należą się odchodzącym generacjom, a nie mnie. Ja chcę wreszcie zakopać trupy i Wołyń, i akcję «Wisła», i wreszcie zacząć żyć (K/40/2016/80)".

\section{Podsumowanie}

Refleksja nad lokalnością Ukraińców z Polski, ich osobną historią, nie w pełni zrozumiałą i czytelną dla innych członków diaspory, wymaga indywidualnego wysiłku i własnych poszukiwań, często dzieje się równolegle z uczestniczeniem w celebracjach pamięci diaspory, takich jak rocznica Wielkiego Głodu czy powstania niepodległego państwa ukraińskiego. Pamięć ta nie ma instytucjonalnego wsparcia ${ }^{7}$. Z uwagi na własne doświadczenia biograficzne, nie tylko emigrację z Polski i życie w wieloetnicznej Kanadzie, ale także liczne podróże odbywane w ciągu życia, Ukraińcy uczynili z miejsca, z którego wyjechali, pewną koncepcję, która nie oznacza bycia zakorzenionym na stałe w jakichś współrzędnych geograficznych. Nie traktują oni miejsca - czy w Polsce, czy w Kanadzie - jako danego raz na zawsze, jako swoistego przypisania. Prezentują raczej postawy obywateli świata, którzy potrafią się dostosować do różnych zmiennych i warunków, i w wielu miejscach odnaleźć siebie. Punktem odniesienia są tutaj również własna rodzina i dzieci, najczęściej urodzone już w Kanadzie. Miejsce Polski w tych refleksjach nadal jest szczególne, bo związane z emocjami i kawałkiem życia, które tam przeżyli, jednak nie oznacza jej wyraźnej dominacji jako swojego miejsca na ziemi. Inaczej wygląda to w przypadku, gdy wciąż żyją rodzice rozmówcy i dom rodzinny jest materialnym, rzeczywistym miejscem na mapie Polski. Wówczas zakres identyfikacji z Polską wyraźnie dominuje. To w domu rodzinnym jest dla nich najbardziej swojsko i bezpiecznie, ale nie jest to kwestia murów lub działki, tylko obecności rodziców czy rodzeństwa. Ci, którzy deklarują największe przywiązanie do Polski i często tam jeżdżą, traktując to jako naturalną potrzebę, zwracają uwagę, że

7 Wyjątkiem są tu torontońskie Towarzystwo „Zakerzonie” i Fundacja Łemkowska, które zajęte są tworzeniem narracji o ukraińskości lokalnej, w konkretnych ramach czasowych i przestrzennych. 
w ten sposób odzyskują psychiczną równowagę i poczucie przynależności, bycia u siebie, którego nie daje im Kanada. Czerpią wówczas z podzielanych wartości, zrozumiałych zachowań i wzorów kulturowych, sięgają po oczywiste znaczenia i symbole. Z opowieści moich rozmówców wynika, że podczas każdego kontaktu z Polską, choćby wirtualnego, dokonują oni swoistej negocjacji czy redefinicji wyobrażonej „polskości” i jej miejsca w granicach własnej tożsamości oraz roli Polski jako idei i terytorium w swojej pamięci.

Jak sugeruje Dan Lainer-Vos (2010), nie ma żadnego powodu, aby porzucić kategorię diaspory. Jeśli będziemy obchodzić się z nią właściwie, może nam dostarczyć użytecznej perspektywy, która pozwala na śledzenie procesu wytwarzania przynależności do miejsc lub grup, tworzenia wyobrażeń, pojęć ojczyzny i diaspory oraz konsumowania ich z pomocą technologii komunikacyjnych. Skupienie się na diasporowych praktykach jest szansą uniknięcia reifikacji diaspory traktowanej jako naturalna całość i zwrócenia uwagi na procesy negocjowania i kontestowania identyfikacji. Rozmaite poziomy i wymiary identyfikacji, poparte praktykami, które śledzę, można rozumieć jako osobne identyfikacje moich rozmówców z diasporą ukraińską w Kanadzie i poszczególnymi jej częściami oraz osobne z Polską bądź Ukrainą. Osoby ukraińskiego pochodzenia z Polski rozwinęły specyficzną formę identyfikacji definiowaną, formułowaną i realizowaną w Kanadzie, niesprowadzalną do relacji z Polską bądź Ukrainą jako państwami narodowymi. Lokują się zatem pomiędzy Kanadą, Polską a diasporą ukraińską jako jej część i jednocześnie osobna grupa, definiując tak swoje położenie i nadając temu sens w codziennych praktykach. Bardzo ważnym punktem odniesienia jest tu pamięć o wysiedleniach - nawet jeśli nie przeżywa się jej aktywnie, to stanowi ona istotny tożsamościowy depozyt. Zwrócenie uwagi na owe praktyki, projekty i sposoby negocjowania oraz kontestowania identyfikacji wydaje mi się kluczowe, ponieważ pozwala na wskazanie obszarów „ciążenia” w kierunku „reszty" diaspory ukraińskiej, negocjacji z miejscowymi Polakami, stopnia i wymiarów przywiązania do Polski jako kraju rodzinnego czy emocjonalnej tęsknoty za idealną, wyśnioną Ukrainą. Daje to możliwość uchwycenia specyfiki grupy niesprowadzalnej do granic żadnej z diaspor.

\section{Bibliografia}

Appadurai A.

2005 Nowoczesność bez granic. Kulturowe wymiary globalizacji, przeł. Z. Pucek, Kraków.

Beck U.

2004 Cosmopolitical Realism: On the Distinction between Cosmopolitanism in Philosophy and the Social Sciences, „Global Networks”, vol. 4, issue 2, s. 131-156.

Brubaker R.

2005 The „Diaspora” Diaspora, „Ethnic and Racial Studies”, vol. 28, no. 1, s. 1-19. 


\section{Clifford J.}

1994 Diasporas, „Cultural Anthropology”, vol. 9, no. 3, s. 302-338.

Creet J.

2011 Introduction: The Migration of Memory and Memories of Migration, w: J. Creet, A. Kitzmann (eds.), Memory and Migration. Multidisciplinary Approaches to Memory Studies, Toronto, s. 3-26.

Hrycak J.

2000 Historia Ukrainy: 1772-1999. Narodziny nowoczesnego narodu, przeł. K. Kotyńska, Lublin.

Iwanyk M.

2011 I ne $v$ doma, I ne na chuzhyni. Emihratsiia ukraintsiv $z$ Pol'shchi u 80-kh rokach XX st., „Ukraiins'kyı̆ almanakh”, s. 240-246.

Lainer-Vos D.

2010 Diaspora-Homeland Relations as a Framework to Examine Nation-Building Processes, „Sociology Compass”, vol. 4, no. 10, s. 894-908.

Luciuk L.

2000 Searching for Place: Ukrainian Displaced Persons, Canada, and the Migration of Memory, Toronto.

Martynowych O.

1991 Ukrainians in Canada. The Formative Years 1891-1924, Edmonton.

Mazurek M.

2010 Społeczeństwo kolejki. O doświadczeniach niedoboru 1945-1989, Warszawa.

Ossowski S.

1967 Analiza socjologiczna pojęcia ojczyzny, w: S. Ossowski, Z zagadnień psychologii społecznej, Warszawa, s. 201-227.

Posern-Zieliński A.

2011 Koncepcja diaspory i problemy jej aplikacji do badań środowisk "polonijnych”, w: M. Michalska (red.), Polacy poza granicami kraju u progu XXI wieku. Różne oblicza polskiej tożsamości, „Archiwum Etnograficzne”, t. 52, Wrocław, s. 23-34.

Quayson A., Daswani G.

2013 Introduction - Diaspora and Transnationalism. Scapes, Scales, and Scopes, w: A. Quayson, G. Daswani (eds.), A Companion to Diaspora and Transnationalism, Oxford, UK, s. 1-26.

Sökefeld M.

2006 Mobilizing in Transnational Space: A Social Movement Approach to the Formation of Diaspora, „Global Networks”, vol. 6, no. 3, s. 265-284.

Szmyt Z.

2010 Transnarodowość $w$ wieloetnicznym społeczeństwie rosyjskim. Przykład imigrantów buriackich w Moskwie, w: Ł. Krzyżowski, S. Urbańska (red.), Mozaiki przestrzeni transnarodowych. Teorie - metody - zjawiska, Kraków, s. 198-210.

Trzeszczyńska P.

2014 „My jeździmy do Polski, bo my tam mamy wspomnienia”. O pamięci Ukraińców $z$ Polski $w$ Kanadzie. Komunikat z badań terenowych, „Prace Etnograficzne”, t. 42, z. 3, s. 257-278.

2016a W stronę etnografii Facebooka. Przypadek badań nad diaspora i pamięcia Ukraińców w Kanadzie, „Zeszyty Etnologii Wrocławskiej”, nr 2, s. 23-44.

2016b Ukrainska diaspora w kanadyjskim Edmonton. Krajobraz etniczny miasta i prowincji a praktyki pamięci, „Etnografia Polska”, t. 60, z. 1-2, s. 83-103. 
2017 Diaspora $w$ diasporze: Ukraińcy $z$ Polski $w$ Toronto. Szkic $z$ antropologii pamięci, „Studia Migracyjne - Przegląd Polonijny", t. 43, z. 1, s. 133-147.

Vertovec S.

2012 Transnarodowość, przeł. I. Kołbon, Kraków.

Wimmer A., Glick Schiller N.

2002 Methodological Nationalism and Beyond: Nation-state Building, Migration and the Social Sciences, „Global Networks”, vol. 2, no. 4, s. 301-334. 